\title{
PENGEMBANGAN MEDIA PEMBELAJARAN PJOK BERBASIS KARTU GERAK AKTIVITAS PENGEMBANGAN UNTUK SISWA KELAS X SMA NEGERI SUKASADA
}

\author{
A.A. Gede Mardiana Putra, I W. Artanayasa, M. A. Wijaya \\ Jurusan Pendidikan Jasmani Kesehatan dan Rekreasi Fakultas Olahraga dan \\ Kesehatan Universitas Pendidikan Ganesha, Kampus FOK Jinengdalem \\ Jalan Jinengdalem Singaraja-Bali Tlp. (0362) 32559 \\ e-mail: \{gunkde79@gmail.com, wayan.artanayasa@undiksha.ac.id, \\ wijaya.madeagus@undiksha.ac.id\}
}

\begin{abstract}
Abstrak
Penelitian ini bertujuan untuk mengembangkan sebuah media pembelajaran PJOK berbasis kartu gerak aktivitas pengembangan untuk siswa kelas X SMA/SMK. Jenis penelitian ini adalah penelitian pengembangan, menggunakan model pengembangan ADDIE yang terdiri dari 5 (lima) tahapan yaitu: tahap analisis (analysis), desain (design), pengembangan (development), implementasi (implementation), evaluasi (evaluation). Penelitian ini dilaksanakan pada 2 (dua) SMA/SMK di Singaraja yaitu SMA Negeri 1 Sukasada dan SMK Negeri 1 Sukasada tahun pelajaran 2018/2019. Penelitian ini melibatkan partisipasi aktif guru PJOK dan siswa pada kelima tahapan pengembangan. Pengumpulan data diperoleh melalui 1) angket analisis kebutuhan, 2) lembar validasi pakar dan praktisi PJOK, 3) angket pendapat guru tentang media pembelajaran dan, 4) angket pendapat siswa tentang media pembelajaran. Hasil penelitian pengembangan ini menunjukan 1) media pembelajaran kartu gerak aktivitas pengembangan sangat dibutuhkan oleh guru dan siswa, 2) tugas gerak pada kartu gerak aktivitas pengembangan telah memenuhi konsep dan teori pembelajaran PJOK, 3) pendapat siswa tentang kartu gerak aktivitas pengembangan diperoleh persentase $99,64 \%$ dengan kategori sangat baik. Berdasarkan hasil penelitian dan pembahasan disimpulkan bahwa media pembelajaran kartu gerak aktivitas pengembangan layak digunakan untuk siswa kelas X SMA/SMK.
\end{abstract}

Kata kunci : PJOK, Kartu Gerak, Aktivitas Pengembangan

\begin{abstract}
This study aimed to develop PJOK learning media based on development cards for $X$ grade students of SMA/SMK. The type of this research was development research using ADDIE development model consist of 5 (five) stages: analysis, design, development, implementation, evaluation. This research was conducted on 2 (two) SMA/SMK which were located in Singaraja namely SMA Negeri 1 Sukasada and SMK Negeri 1 Sukasada in academic year 2018/2019. The research involved active teachers of PJOK and students in five stages of development. Data collection was obtained through 1) questionnaire of analysis needs, 2) expert validation sheet and PJOK practitioner, 3) teachers' opinion questionnaire about instructional media and, 4) students' opinion questionnaire about learning media. The result of the research shows that 1) learning media of development activity motion card is needed by teacher and student, 2) tasks on development activity motion card have fulfilled the concept and learning theory of PJOK, 3) the students' opinions about the development activity motion card obtained percentage 99.64\%
\end{abstract}


with very good category. Based on the result of research and discussion, it is concluded that learning media of development activity motion card is suitable for high school / vocational school students.

Keywords: PJOK, Motion Card, Development Activity.

\section{PENDAHULUAN}

Perkembangan gerak pada siswa bisa terjadi dengan baik apabila memperoleh kesempatan cukup besar untuk melakukan aktivitas fisik dalam bentuk gerakan-gerakan yang melibatkan keseluruhan bagian anggota tubuhnya, sehingga siswa akan mampu mengusai keterampilan gerak dengan baik. Pentingnya tugas gerak bagi guru PJOK adalah menerapkan tugas gerak yang sesuai dengan karakteristik siswa. Tugas gerak yang dikatakan sesuai bagi siswa adalah tugas gerak gerak yang sesuai dengan karakteristik dan kebutuhan dilakukan secara bertahap dari tingkatan yang mudah sampai tingkatan sulit, dari sederhana ke kompleks dengan tetap menjaga keselamatan siswa.

Membahas hakikat pembelajaran PJOK kurang lengkap apabila belum membahas tentang pengertian dari pembelajaran dan pengertian PJOK. Menurut Dimyati dan Mudjiono (2013:157) "Pembelajaran adalah suatu proses belajar yang diselenggarakan oleh guru untuk membelajarkan siswa dalam memperoleh pengetahuan, keterampilan dan sikap.

Menurut Permendiknas Nomor 22 Tahun 2006 penjasorkes adalah bagian integral dari sistem pendidikan nasional secara keseluruhan, bertujuan untuk mengembangkan aspek kesehatan, kebugaran jasmani, keterampilan berpikir kritis, stabilitas emosional, keterampilan sosial, penalaran, dan tindakan moral melalui aktivitas jasmani dan olahraga.

Peneliti pada saat melaksanakan observasi pada Rabu, 17 Januari 2018 di
SMA Negeri 1 Sukasada pada khususnya pada materi aktivitas pengembangan menemukan bahwa guru PJOK belum sepenuhnya mampu menyediakan tugas gerak yang sesuai dengan karakteristik siswa. Terlihat guru masih memberikan tugas gerak yang masih monoton, sehingga siswa cenderung kurang antusias dalam proses pembelajaran, terlebih hal tersebut juga disebabkan penggunaan pada media pembelajaran yang bersifat terbatas, yaitu jumlahnya hanya satu dan ditempatkan pada satu titik. Guru PJOK secara ideal sangat membutuhkan keberadaan media pembelajaran yang dapat diakses dengan mudah oleh siswa sehingga waktu aktif berlatih atau belajar untuk siswa menjadi meningkat. Salah satu fungsi utama media pembelajaran adalah sebagai alat bantu mengajar yang turut memotivasi

Terdapat 6 pertimbangan dalam memilih media pembelajaran yang tepat, yaitu (1) access yaitu kemudahan penggunaan dan kebermanfaatan media, (2) cost yaitu biaya yang dibutuhkan dengan pertimbangan aspek manfaat, (3) technology yaitu media berbasis teknologi perlu memperhatikan keberadaan teknisi dan kemudahan penggunaannya, (4) interactivity yaitu munculnya komunikasi dua arah, (5) organization yaitu lembaga atau organisasi yang mendukung pembuatan media, (6) novelty yaitu kebaruan media dapat membuat siswa lebih tertarik. Madia pembelajaan yang digunakaan dapat berupa media audio, visual maupun audio -visual. Penggunaan media pembelajaran yang tepat diyakini akan meningkatkan partisifasi siswa sehingga tujuan dari pembelajaran siswa dapat tercapai.

Penelitian yang berkaitan dengan media pembelajaran PJOK telah diteliti antara lain oleh I Gusti Bagus Maha Aryasa (2017:85) mengemukakan bahwa media pembelajaran kartu bergambar 
telah memenuhi kelayakan aspek desain dan layak dipergunakan oleh siswa, Penelitian Made Agus Wijaya, (2016:194) menemukan bahwa kartu gerak seri gerak dasar efektif meningkatkan keterampilan gerak dasar siswa.

Tujuan pembelajaran PJOK di SMA/SMK secara umum diantaranya: 1) pengembangan dan pemeliharaan kebugaran jasmani serta pola hidup sehat melalui berbagai aktiftas jasmani dan olahraga yang terpilih, dan (2) meletakan landasan karakter pola yang kuat melalui internalisasi nilai - nilai yang terkandung dalam PJOK. Pengembangan dan pemeliharaan kebugaran jasmani di tempuh melalui materi aktivitas pengembangan. Sehat jasmani sebagai salah satu tujuan pembelajaran PJOK dapat dilihat dari tingkat kebugaran jasmani peserta didik. Sayangnya, berdasarkan observasi terkait mengenai kebugaran jasmani di sekolah menengah menyebutkan bahwa tingkat kebugaran jasmani peserta didik masih tergolong rendah.

Hal tersebut dikuatkan oleh penelitian sebelumnya tentang kebugaran jasmani baik secara lokal maupun nasional itu terlihat dari hasil penelitian yang dilakukan oleh I Ketut Yoda (2008), bahwa tingkat kebugaran jasmani siswa kelas XI dan XII SMA Negeri 4 Singaraja Buleleng Bali tahun pelajaran 2008/2009, tergolong kurang sekali (64\%). Hanya $2 \%$ saja tingkat kebugaran jasmani siswa tergolong baik. Kebugaran jasmani. menurut Rulsi Lutan (2002:62) mengandung arti sebagai kemampuan individu untuk melakukan aktivitas fisik umum maupun khusus dalam kehidupan sehari-hari secara efisien tanpa mengalami kelelahan berarti dan masih memiliki cadangan energi untuk mengatasi beban kerja tambahanHasil serupa mengenai tingkat kebugaran jasmani yang tergolong rendah juga dikemukakan berdasarkan hasil Sport Develompment Index (SDI) yang mengukur 4 (empat) dimensi pembangunan olahraga Indonesia yaitu ruang terbuka, sumber daya manusia, partisipasi masyarakat serta kebugaran jasmani. Berdasarkan data SDI tahun
2006 menyebutkan bahwa, khusus pada aspek kebugaran jasmani, 37,40\% masyarakat Indonesia memiliki kebugaran jasmani pada kategori kurang sekali; 43,90\% kurang; $13,55 \%$ sedang; 4,07\% baik; dan hanya $1,08 \%$ masyarakat Indonesia termasuk pada kategori baik sekali. Rendahnya tingkat kebugaran jasmani peserta didik pada semua tingkat satuan pendidikan di Indonesia dapat dijadikan satu petunjuk umum bahwa mutu program PJOK di Indonesia masih perlu ditingkatkan.

Tidak berbeda jauh dengan pandangan peneliti terkait kebugaran jasmani, saat ini media publik (facebook, koran, majalah) banyak membahas tentang dekadensi moral siswa dan masyarakat. Fenomena geng motor, perkelahian antar siswa, bullying, pelecehan seksual, dan penyalahgunaan narkoba menjadi berita utama (headline) media publik. Kejadian terkini adalah kasus pembunuhaan seorang guru yang dilakukan oleh siswa di Sampang, Madura yang mejadi viral. Hal ini tentunya menjadi perhatian yang serius salah satunya oleh guru PJOK.

Dilihat dari tingkat ketercapaian tujuan pembelajaran di SMA Negeri 1 Sukasada, berdasarkan hasil diskusi dengan narasumber guru PJOK atas nama I Made Sudiyasa, S.Pd., menyebutkan bahwa: (1) mata pelajaran PJOK materi aktivitas pengembangan secara kognitif tergolong baik dan dapat dikatakan tuntas. Beliau menyatakan nilai rata-rata pada mata pelajaran PJOK materi aktivitas pengembangan kelas $X$ semester I tahun pelajaran 2017/2018 secara umum sudah baik atau berada pada rentang di atas rata-rata KKM yaitu 77, (2) pembelajaran kebugaran jasmani lebih dominan pada aspek teoritik yang disampaikan berbantuan buku pegangan siswa dan belum sepenuhnya diterapkan praktinya, (3) belum adanya media pembelajaran aktivitas pengembangan.

Media pembelajaran sebenarnya merupakan alat bantu yang berguna bagi pendidik dalam membantu tugas kependidikannya. Secara umum, media pembelajaran berfungsi mengarahkan siswa untuk memperoleh berbagai 
pengalaman belajar. Pengalaman belajar tergantung adanya interaksi siwa dengan media. Dengan penggunaan media yang tepat dan sesuai dengan tujuan pembelajaran, tentunya akan dapat mempertinggi hasil belajar. Keterbatasan media pembelajaran dan kurangnnya kreativitas guru menyebabkan guru mengajarkan materi PJOK hanya sebatas teori saja. Sangat disayangkan apabila hal ini terus berlanjut dimana sesungguhnya hasil belajar siswa masih bisa ditingkatkan bila kondisi pembelajaran didukung oleh strategi dan media yang memadai. Peningkatan kualitas pembelajaran yang akan berdampak pada meningkatnya hasil belajar memerlukan berbagai upaya. Salah satunya adalah pemanfaatan media pembelajaran yang sesuai dengan kebutuhan dan karakteristik siswa yang diharapkan mampu menciptakan pembelajaran yang efektif dan efisien. Dengan begitu siswa lebih mudah menyerap materi pembalajaran. Selain itu juga, media dapat digunakan di luar jam pelajaran mengingat keterbatasan jam pelajaran aktivitas pengembangan di SMA Negeri 1 Sukasada mencangkup kelentukan, keseimbangan, kecepatan, kelincahan,daya tahan dan kekuatan. Sampai saat ini belum ada media pembelajaran PJOK yang memuat tugas gerak pada materi aktivitas pengembangan yang dipadukan dengan nilai karakter untuk siswa. Berdasarkan uraian diatas peneliti tertarik meneliti tentang media pembelajaran PJOK berbasis kartu geak pada materi aktivitas pengembangan untuk siswa kelas X SMA Negeri 1 Sukasada.

\section{METODE PENELITIAN}

Penelitian ini merupakan penelitian pengembangan yang bertujuan untuk mengembangkan media pembelajaran kartu gerak aktivitas pengembangan untuk siswa kelas $X$ SMA/SMK. Penelitian pengembangan ini menggunakan model pengembangan ADDIE meliputi 5 tahap yaitu: 1) analisis (analysis), 2) desain (design), 3) pengembangan (development)
4) implementasi (implementation),
5) evaluasi (evaluation).

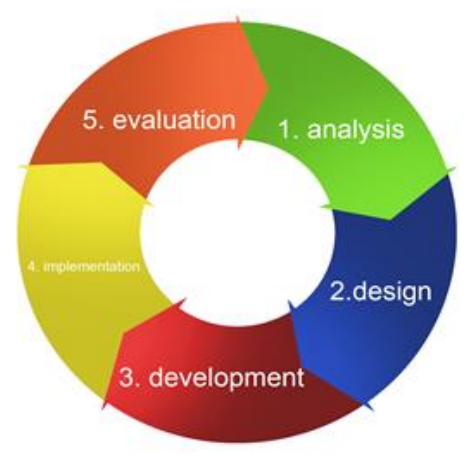

Gambar 1

Tahapan Model Pengembangan ADDIE (Sumber : Zuhdan K. Prasetyo 2013:4)

Prosedur penelitian pengembangan merupakan tahapan-tahapan dari proses pengembangan yang akan dilakukan. Prosedur pengambangan sendiri berguna untuk lebih memperjelas tentang bagaimana langkah prosedural yang harus dilalui agar sampai ke produk yang diharapkan.

Pada Tahap analisis tahapan pertama pada penelitian ini terdiri 2 (dua) kegiatan yaitu : 1) Menganalisis kurikulum PJOK (KI, KD dan materi) kelas X SMA, dan 2) Menganalisis kebutuhan guru PJOK terhadap media pembelajaran. Analisis kebutuhan dilaksanakan dengan malakukan kegiatan-kegiatan observasi dan penyebaran angket/kuisioner analisa kebutuhan kepada guru PJOK dan siswa.

Tahap kedua dalam penelitian ini adalah tahap desain, dalam tahap desain terdiri dari 4 (empat) kegiatan yaitu : 1) membuat identifikasi tugas gerak, 2) membuat desain katu gerak sisi pertama yang memuat gambar, tugas gerak dan nilai positif PJOK, 3) Focus Group Discussion (FGD) bersama pakar dan prktisi, guru PJOK SMA Negeri 1 Sukasada dan SMK Negeri 1 Sukasada, 4) Revisi desain.

Tahap ketiga dalam penelitian ini adalah tahap pengembangan. tahap pengembangan pada penelitian ini mencangkup 2 (dua) kegiatan yaitu: 1) uji coba produk pertama, untuk memastikan 
siswa dapat melakukan semua tugas gerak yang dirancang, dan 2) uji coba produk pertama tahap kedua dengan jumlah 5-10 orang siswa dengan proses pembelajaran yang sesungguhnya.

Tahap keempat dalam penelitian ini adalah tahap implementasi. Kegiatan yang mencangkup dalam tahap implementasi adalah uji produk dengan proses pembelajaran yang sesungguhnya dengan melakukan uji coba pada kelas yang dipilih.

Tahap terakhir dalam penelitian pengembangan merupakan tahap evaluasi (evaluation) dalam penelitian ini tahap evaluasi sebetulnya sudah ada di masingmasing tahapan baik dari tahap 1) analisis ,2) desain, 3) pengembangan, 4) implementasi.

Instrumen pengumpulan data dalam penelitian ini merupakan alat bantu yang digunakan peneliti dalam pengumpulan data. Pengumpulan data diperoleh melalui 1) angket analisis kebutuhan, 2) lembar validasi pakar dan praktisi PJOK, 3) angket pendapat guru tentang media pembelajaran dan, 4) angket pendapat siswa tentang media pembelajaran.

Analisi data yang digunakan dalam penelitian ini, adalah deskriptif kualitatifkuantitatif. Deskriptif kualitatif untuk menganalisis informasi tentang berbagai kondisi lapangan yang bersifat masukan dan saran guru PJOK dan siswa terhadap media pembelajaran yang diperoleh melalui kuesioner terbuka. Kedua, analisis deskriptif kuantitatif digunakan menganalisis skor yang diberikan oleh guru PJOK dan siswa terhadap media pembelajaran yang diperoleh melalui kuesioner tertutup. Teknik analisis ini digunakan untuk mengolah data yang diperoleh melalui angket dalam bentuk deskriptif persentase. Pemberian skor dilakukan dengan cara pemberian penilaian disetiap instrumen pengumpulan data dengan Sekor Maksimal Intrumen (SMI) adalah maksimal 5 (lima). Menurut Tegeh dan Kirna (2010:101) Rumus yang digunakan untuk menghitung persentase dari masing-masing subjek adalah:
Persentase

$$
\frac{\sum(\text { Jawaban } x \text { Bobot tiap pilihan })}{n \times \text { bobot tertinggi }} \times 100 \%
$$

Keterangan $\Sigma=$ jumlah

$$
\mathrm{N}=\text { jumlah seluruh item angket }
$$

Persentase : $\mathrm{F}: \mathrm{N}$

$\mathrm{F}=$ jumlah persentase keseluruhan subjek $\mathrm{N}$ = banyak subjek

\section{HASIL DAN PEMBAHASAN}

Menurut hasil pengembangan Sesuai dengan rancangan penelitian ini model pengembangan yang digunakan adalah model pengembangan ADDIE, yang terdiri dari 5 (lima) tahap yaitu: 1) analisis 2) desain 3) pengembangan 4) implementasi dan 5) evaluasi

Hasil dari analisis kebutuhan menunjukan 4bahwa guru PJOK memanfaatkan media pembelajaran visual dan audio-visual berupa media gambar, televisi, VCD maupun LCD. Namun, menurut guru PJOK belum pernah membuat tugas gerak dengan kombinasi media gambar dalam sebuah kartu. Sehingga guru PJOK sangat membutuhkan terwujudnya kartu gerak aktivitas pengembangan.

Hasil dari tahap pertama dalam penelitian ini adalah analisi kebutuhan yang mencangkup Kurikulum, Kompetensi Inti (KI), Kompetensi Dasar (KD), tujuan pembelajaran dan materi pembelajaran. Kurikulum yang berlaku untuk siswa kelas $X$ adalah Kurikulum 13. Kurikulum 13 yang digunakan di kelas $X$ ini terdapat materi aktivitas pengembangan yang terdiri dari 6 (enam) komponen kebugaran jasmani yaitu: 1) kekuatan, 2) kelentukan, 3) kelincahan, 4) daya tahan keseimbangan, 5), dan 6) kecepatan.

Tahap kedua dalam penelitian ini adalah tahap desain. Pada penelitian ini teradapat 3 (tiga) kegiatan yaitu: 1) mendesain bentuk tugas gerak, 2) melaksanakan Focus Group Discussion (FGD) bersama pakar dan praktisi, guru PJOK SMA Negeri 1 Sukasada dan SMK 
Negeri 1 Sukasada dan, 3) membuat desain kartu gerak tampilan depan, belakang yang memuat gambar tugas

tugas gerak. Target capaian kegiatan ini adalah desain media pembelajaran PJOK dengan alat bantu kartu gerak, cara pencapaian kegiatan tersebut adalah dengan mendesain draf tugas gerak. Langkah awal yang peneliti laksanakan pada tahap pembuatan desain kartu gerak adalah merancang dan menentukan masing-masing komponen gerak aktivitas pengembangan. Materi aktivitas pengembangan sesuai dengan Kurikulum 13 terdapat 6 (enam) komponen gerak aktivitas pengembangan yaitu 1) kekuatan, 2) keseimbangan, 3) kelentukan, 4) kelincahan, 5) daya tahan, dan 6) kecepatan, dengan masingmasing komponen gerak mempunyai 2 pilihan tugas gerak dan contoh gerakan berdasarkan tingkatan kesulitan mudah, sedang dan sulit. Sehingga dalam satu set kartu gerak terdapat 36 (tiga puluh enam) buah gerakan.

Focus Group Discussion (FGD) merupakan kegiatan ke 2 (dua) pada tahapan desain (design) FGD dimana mendapatkan hasil perbaikan berdasarkan masukan dan saran yang diberikan oleh pembimbing dan paktisi PJOK. Secara umum jenis gerakan tiap satu set kartu gerak tetap sebanyak 36 (tiga puluh enam) kartu gerakan namun perbaikan lebih banyak pada judul atau bentuk tugas gerak. Selanjutnya contoh gerakan dikembangkan menjadi tugas gerak dalam pembelajaran PJOK. Salah satu contoh perbaikan model pengembangan kartu gerak aktivitas pengembangan pada tingkat kesulitan mudah, sedang dan sulit terlihat pada komponen kelincahan. Pada draf pertama, contoh gerakan pada tingkat kesulitan gerak, nilai positif PJOK dan kotak kemasan kartu.

Kegiatan pertama dalam tahap desain (design) adalah mendesain draf sedang adalah lompat kedepan kerucut berulang ulang. Hasil FGD contoh gerakan tersebut merupakan salah satu gerak bukan komponen kelincahan namun gerakan tersebut menurut hasil FGD adalah contoh komponen kekuatan otot tungkai, sehingga hasil diskusi tugas gerak diperbaiki menjadi lari menyamping.

Kegiatan ketiga yang dilaksanakan pada tahap desain (design) adalah membuat desain kartu gerak tampilan depan, belakang yang memuat gambar tugas gerak dan nilai positif PJOK. Penelitian ini merupakan hasil dari pengembangan desain kartu gerak yang tidak terlepas dari kegiatan pertama dan kedua. Secara umum draf model final yang dihasilkan berupa: (1) kartu gerak seri aktivitas pengembangan yang terdiri 36 kartu gerak dalam 1 set dengan rincian 6 komponen aktivitas pengembangan, (2) masing-masing komponen mempunyai 2 pilihan tugas gerak 3) kartu gerak yang dihasilkan berdasarkan atas tingkat kesulitan gerak yaitu mudah, sedang dan sulit, dan (4) kartu gerak terdiri atas tampilan depan dan tampilan belakang.

Tahap ketiga dalam penelitian ini adalah tahap pengembangan Tahap pengembangan. Pada penelitian ini mencangkup 2 (dua) kegiatan yaitu: 1) uji coba produk pertama, memastikan siswa dapat melakukan tugas gerak dan 2) uji coba produk pertama tahap kedua dengan sekian orang siswa dengan proses pembelajaran yang sesungguhnya.

Hasil dari uji produk pertama didapatkan tanggapan siswa sebanyak 10 orang siswa dapat dilihat pada tabel berikut.

Tabel 1

Hasil Uji Coba Pertama Terhadap Media

\begin{tabular}{ccccl}
\hline No & Responden & Skor & Persentase \% & Kualifikasi \\
\hline 1 & A1 & 30 & 83 & Baik \\
2 & A2 & 31 & 86 & Baik
\end{tabular}




\begin{tabular}{ccccl}
3 & A3 & 36 & 100 & Sangat Baik \\
4 & A4 & 36 & 100 & Sangat Baik \\
5 & A5 & 36 & 100 & Sangat Baik \\
6 & A6 & 36 & 100 & Sangat Baik \\
7 & A7 & 36 & 100 & Sangat Baik \\
8 & A8 & 36 & 100 & Sangat Baik \\
9 & A9 & 36 & 100 & Sangat Baik \\
10 & A10 & 30 & 83 & Baik \\
& Jumlah & $\mathbf{3 4 3}$ & $\mathbf{9 5 3}$ & Sangat Baik \\
\hline
\end{tabular}

Hasil dari 10 (sepuluh) orang siswa didapatkan tanggapan siswa sebanyak 7 (tujuh) orang siswa menyatakan kartu gerak aktivitas pengembangan pada kategori "sangat baik" dan 3 (tiga) orang siswa menyatakan "baik", dilihat dari segi pernyataan kuisioner pendapat siswa SMA/SMK dengan persentase $953 \%$ sebagaimana dicantumkan pada tabel. Hasi persentase tingkat pencapaian media dihitung dengan rumus $\mathrm{F}: \mathrm{N}$ dimana $\mathrm{F}=953$ dibagi $\mathrm{N}=10$ diperoleh rata-rata $95.30 \%$. Ini artinya media pembelajaran kartu gerak aktivitas pengembangan berada pada kategori "sangat baik"

Hasil dari uji produk pertama tahap kedua didapatkan tanggapan siswa sebanyak 10 orang siswa dapat dilihat pada tabel berikut.

Tabel 2

Hasil Uji Coba Pertama Terhadap Media

\begin{tabular}{|c|c|c|c|c|}
\hline No & Responden & Skor & Persentase \% & Kualifiasi \\
\hline 1 & A1 & 36 & 100 & Sangat Baik \\
\hline 2 & A2 & 36 & 100 & Sangat Baik \\
\hline 3 & A3 & 32 & 89 & Baik \\
\hline 4 & A4 & 36 & 100 & Sangat Baik \\
\hline 5 & A5 & 36 & 100 & Sangat Baik \\
\hline 6 & A6 & 36 & 100 & Sangat Baik \\
\hline 7 & A7 & 36 & 100 & Sangat Baik \\
\hline 8 & A8 & 36 & 100 & Sangat Baik \\
\hline 9 & A9 & 36 & 100 & Sangat Baik \\
\hline \multirow[t]{2}{*}{10} & A10 & 30 & 83 & Baik \\
\hline & Jumlah & 350 & 972 & Sangat Baik \\
\hline
\end{tabular}

Hasil dari 10 (sepuluh) orang siswa didapatkan tanggapan siswa sebanyak 8 (sembilan) orang siswa menyatakan kartu gerak aktivitas pengembangan pada kategori "sangat baik" dan 2 (dua) orang siswa menyatakan "baik". Dilihat dari segi pernyataan kuisioner pendapat siswa SMA/SMK dengan persentase $972 \%$ sebagaimana dicantumkan pada tabel. Hasi persentase tingkat pencapaian media dihitung dengan rumus $\mathrm{F}: \mathrm{N}$ dimana $\mathrm{F}=972$ dibagi $\mathrm{N}=10$ diperoleh rata-rata $97.20 \%$. Ini artinya media pembelajaran kartu gerak aktivitas pengembangan berada pada kategori "sangat baik"

Berdasarkan hasil uji coba produk pertama dan kedua dari tahap pengembangan telah selesai diperoleh masukan dari siswa dengan presentase 
sebagai berikut. 1) rata-rata $96,25 \%$ siswa menyatakan tampilan pada kartu gerak terlihat jelas, 2) tulisan pada kartu gerak dapat dibaca dengan jelas 3) kartu gerak mudah dibawa/ praktis dan 4) kertas kartu gerak aman dan nyaman digunakan.

Tahap keempat dalam penelitian ini adalah tahap implementasi. Kegiatan yang mencangkup dalam tahap implementasi adalah uji produk pada proses pembelajaran pada kelas yang sesungguhnya.

Hasil dari uji coba pada proses pembelajaran yang sesungguhnya

\section{Tabel 3}

Hasil Uji Coba Pertama Terhadap Media didapatkan tanggapan siswa sebanyak 20 orang siswa kelas $X$ SMA Negeri 1 Sukasada. Hasil dari 20 (dua puluh) orang siswa didapatkan tanggapan siswa sebanyak 20 (dua puluh) orang siswa menyatakan media pembelajaran kartu gerak aktivitas pengembangan pada kategori "sangat baik" dilihat pada tabel berikut.

\begin{tabular}{|c|c|c|c|c|}
\hline No & Responden & Skor & Persentase \% & Kualifikasi \\
\hline 1 & A1 & 41 & 98 & Sangat Baik \\
\hline 2 & $\mathrm{~A} 2$ & 42 & 100 & Sangat Baik \\
\hline 3 & A3 & 42 & 100 & Sangat Baik \\
\hline 4 & A4 & 42 & 100 & Sangat Baik \\
\hline 5 & A5 & 41 & 98 & Sangat Baik \\
\hline 6 & A6 & 42 & 100 & Sangat Baik \\
\hline 7 & A7 & 42 & 100 & Sangat Baik \\
\hline 8 & A8 & 42 & 100 & Sangat Baik \\
\hline 9 & A9 & 42 & 100 & Sangat Baik \\
\hline 10 & A10 & 42 & 100 & Sangat Baik \\
\hline 11 & A11 & 42 & 100 & Sangat Baik \\
\hline 12 & A12 & 42 & 100 & Sangat Baik \\
\hline 13 & A13 & 41 & 98 & Sangat Baik \\
\hline 14 & A14 & 42 & 100 & Sangat Baik \\
\hline 15 & A15 & 42 & 100 & Sangat Baik \\
\hline 16 & A16 & 42 & 100 & Sangat Baik \\
\hline 17 & A17 & 42 & 100 & Sangat Baik \\
\hline 18 & A18 & 42 & 100 & Sangat Baik \\
\hline 19 & A19 & 42 & 100 & Sangat Baik \\
\hline 20 & A20 & 42 & 100 & Sangat Baik \\
\hline \multicolumn{2}{|r|}{ Jumlah } & 837 & 1993 & Sangat Baik \\
\hline
\end{tabular}

Dilihat dari segi pernyataan kuisioner pendapat siswa SMA/SMK dengan persentase $1993 \%$ sebagaimana dicantumkan pada tabel. Hasi persentase tingkat pencapaian media dihitung dengan rumus $\mathrm{F}: \mathrm{N}$ dimana $\mathrm{F}=1993$ dibagi $\mathrm{N}=$ 20 diperoleh rata-rata $99.64 \%$. Ini artinya media pembelajaran kartu gerak aktivitas pengembangan berada pada kategori "sangat baik"

Hasil produk kartu gerak aktivitas pengembangan memang menunjukan hasil "baik". Beberapa penelitian lain juga telah membuktikan bahwa pembelajaran dengan media bergambar dapat meningkatkan hasil belajar siswa Salah 
satunya adalah penelitian oleh (Maryani, Sri. Martha, Nengah. Artawan, 2013) yang berjudul "Penggunaan Media Gambar Untuk Meningkatkan Kemampuan Menulis Teks Berita Siswa Kelas VIII SMPN 4 Soromadi Kabupaten Bima NTB" menyimpulkan bahwa dengan menggunakan media gambar dalam menulis teks berita dapat meningkatkan kemampuan menulis teks berita siswa. Demikian pula penelitian oleh (Wijawa, 2012) yang berjudul "Developing Fundamental Movement Based Cooperative Learning Model in Primary School" mengemukakan bahwa: Model pembelajaran kooperatif berbasis gerakan dasar dengan bantuan kartu bergerak telah terbukti praktis dan efektif.

\section{SIMPULAN DAN SARAN}

Berdasarkan hasil analisi data dan pembahasan simpulan dari penelitian ini adalah media pembelajaran kartu gerak aktivitas pengembangan ini sangat dibutuhkan oleh guru dan siswa, tugas gerak pada kartu gerak aktivitas pengembangan telah memenuhi konsep dan teori pembelajaran PJOK, pendapat siswa tentang kartu gerak aktivitas

\section{DAFTAR PUSTAKA}

Artanayasa, I Wayan. 2016 Pengembangan Bahan Ajar TP Sepak Takraw dilengkapi Bahan Audiovisual untuk Meningkatkan Kompetensi Mahasiswa Jurusan Penjaskesrek Fok Undiksha. ISSN 2549-2780. Tersedia pada http://artanayasaiwayan.blogspot.c om/2016/02/pengembangan bahan-ajar-tp-sepak-takraw.html Dakses pada 10 Juni 2018

Budaya Astra, I Ketut. 2017. Developing Instructional Material for Sepak Takraw Playing Technique Course Completed with Smart Audiovisual to Improve Competencies of the Students of Sport \& Health Education Department Ganesha University of Education. Tersedia Pada pengembangan diperoleh persentase 99,64\% dengan kategori sangat baik.

Dengan demikian hasil dari hasil penelitian dan pembahasan disimpulkan media pembelajaran kartu gerak aktivitas pengembangan layak digunakan untuk siswa SMA/SMK.

Saran dari penelitian ini adalah Pengembangan Media pembelajaran PJOK berbasis kartu gerak akan lebih terlaksana lebih optimal apabila guru PJOK memiliki pemahaman secara komprehensif tentang karakteristik kartu gerak aktivitas pengembangan dan pelaksanaan media pembelajaran aktivitas pengembangan dengan alat bantu kartu gerak ini. Media pembelajaran aktivitas pengembangan berbasis kartu gerak ini dapat dikembangkan oleh guru PJOK pada materi lain misalnya kartu gerak seri atletik, ataupun kartu gerak seri senam. Apabila peneliti lain yang ingin mengembangkan model pembelajaran yang sejenis, maka dapat menggunakannya pada ruang lingkup pembelajaran PJOK yang lain atau pada jenjang pendidikan SD dan SMP bahkan di perguruan tinggi.

https://www.researchgate.net/publi
cation/318459330 Developing Ins
tructional Material for Sepak Tak
raw Playing Technique Course
Completed with Smart Audiovisu
al to Improve Competencies of t
he Students of Sport Health Ed
ucation Department Ganesha Un
iver?ev=auth pub Diakses Pada
10 Juni 2018

Dimyati \& Mudjiono. 2013. Belajar dan Pembelajaran. Jakarta: Rineka Cipta

Suwiwa, I.G, Santayasa I.W, Kirna,I.M.2014. Pengembangan Multimedia Interaktif Pembelajaran Pada Mata Kuliah Teori Dan Praktik Pencak Silat. Trsedia pada https://scholar.google.co.id/citation s?viewop=view citation\&hl=id\&use $\underline{r=3 J 1 e W Y s A A A A J \& c i t a t i o n ~ f o r ~ v i ~}$ 
ew=3J1eWYsAAAAJ:U5HHmVD u O8C Diakses pada 10 Maret 2018

Yoda, I Ketut, 2008. Korelasi Antara Vo2 Maks Dengan Prestasi Belajar Siswa Kelas XI dan XII SMA Negeri 4 Singaraja Tahun

http://pps.unj.ac.id/journal/ijer_Diaskes Pada 10 Juni 2018
Pelajaran 2008/2009. Singaraja: Undiksha.

Wijaya, Made Agus. 2015. Developing Fundamental Movement Based Cooperative Learning Model in Primary School. Vol. 2. No. 1. ISSN 2335-8407. Tersedia pada 